\title{
Avoiding complication of volar locked plates
}

\author{
Marcos Sanmartin Fernandez \\ From 10th Congress of the Asia-Pacific Federation of Societies of Surgery fo the Hand and the 6th Congress \\ of Asia-Pacific Federation of Societies of Hand Therapists \\ Kuala Lumpur, Malaysia. 2-4 October 2014
}

Volar locking plates are designed to improve and maintain anatomic alignment, even in patients with dorsal comminution and poor metaphyseal bone quality. Its widespread use led to specific complications. Most part is related to tendon, nerve and complex regional pain syndrome [1] and could be avoided by meticulous attention to detail and surgical experience [2].

Tendon and articular injury complications can be prevented by careful avoidance of dorsal cortex and intraarticular screw penetration, use of the low profile plates, and careful placement of the plate proximal to the watershed line.

Most frequent tendons affected are Extensor Policis Longus (EPL) and Flexor Policis Longus (FPL). EPL tendon rupture can occur after a distal radius fractures even when not fixed by a plate [3].

Use of standard intraoperative fluoroscopy imaging is crucial to assess dorsal cortex screw penetration. Lister tubercle can mask prominent screws tips and lateral images have limited sensibility particularly among less experienced observers and for the evaluation of the most ulnar screw positions [4].

Irritation or rupture of flexor tendons, especially the FPL, depends on the position of the plate [5].

Assessment of articular penetration of the screws is critical. Routine use of articular views [6], as well as a $45^{\circ}$ pronated oblique view [7] in doubtful cases, is mandatory during placement of each screw.

Postoperative nerve dysfunction is one of the most common complications, especially median nerve dysfunction [1].

K-wires used for provisional and supplementary fixation can be a source of complications. Such complication may be caused by superficial radial nerve irritation due to K-wire placement during fracture reduction.

Department of Orthopaedics and Traumatology, Hospital Povisa, Vigo, 36211, Spain 
10. Gyuricza C, Carlson MG, Weiland AJ, Wolfe SW, Hotchkiss RN, Daluiski A: Removal of Locked Volar Plates After Distal Radius Fractures. J Hand Surg 2011, 36(6):982-985.

doi:10.1186/1753-6561-9-S3-A42

Cite this article as: Fernandez: Avoiding complication of volar locked plates. BMC Proceedings 2015 9(Suppl 3):A42.

Submit your next manuscript to BioMed Central and take full advantage of:

- Convenient online submission

- Thorough peer review

- No space constraints or color figure charges

- Immediate publication on acceptance

- Inclusion in PubMed, CAS, Scopus and Google Scholar

- Research which is freely available for redistribution

Submit your manuscript at www.biomedcentral.com/submit

() Biomed Central 